\title{
Habitat selection by anurofauna community at rocky seashore in coastal Atlantic Forest, Southeastern Brazil
}

\author{
Pontes $^{a} *, R C$., Santori ${ }^{b}, R T$., Gonçalves e Cunha ${ }^{b, c}, F C$. and Pontes ${ }^{b, c}, J A L$. \\ ${ }^{a}$ Departamento de Vertebrados, Museu Nacional, Universidade Federal do Rio de Janeiro, Quinta da Boa Vista s/n, \\ São Cristóvão, CEP 20940-040 Rio de Janeiro, RJ, Brasil \\ ${ }^{b}$ Departamento de Ciências, Faculdade de Formação de Professores, Universidade do Estado do Rio de Janeiro, \\ Rua Dr. Francisco Portela, 1470, Patronato, CEP 24435-000, São Gonçalo, RJ, Brasil \\ ${ }^{c}$ Laboratório de Ecologia de Vertebrados, IBRAG/Universidade do Estado do Rio de Janeiro, \\ Rua São Francisco Xavier, 524, Maracanã, CEP 20550-011, Rio de Janeiro, RJ, Brasil \\ *e-mail: rafaelcunhapontes@hotmail.com \\ Received June 13, 2012 - Accepted September 20, 2012 - Distributed August 31, 2013
}

(With 3 figures)

\begin{abstract}
Rocky seashores are low granitic hills distributed along the southeastern Brazilian coast with xeric-like vegetation due to the shallow soil. Knowledge on amphibian communities and their reproductive patterns is especially reduced on this kind of environment. Herein, we present a framework of two years monitoring an amphibian community at a rocky seashore environment located at the protected area of Parque Estadual da Serra da Tiririca, municipality of Niterói, state of Rio de Janeiro, Brazil. We conducted diurnal and nocturnal searches for frogs in tank bromeliads, rocky surface and shrubby vegetation. Annual pattern of breeding activity of anurans was also estimated. Individuals of the most abundant tank-bromeliad, Alcantarea glaziouana were collected and measured according to several variables to understanding the selection of bromeliads by frogs. We checked the influence of the environmental conditions on amphibian abundance, association between the bromeliads measures, and the water storage in the tank. We recorded the species: Scinax aff. $x$-signatus; $S$. cuspidatus; $S$. littoreus; Thoropa miliaris and Gastrotheca sp. Bromeliads were the preferential habitat used by anurans. The nocturnal habit was predominant for all species and during diurnal searches, the specimens were found sheltered in bromeliads axils. The number of calling males as well as amphibian abundance was associated with the rainiest and warmest period of the year. The species $S$. littoreus was observed in breeding activity in the majority of sample period. Adult calling males of T. miliaris were observed especially in the rainy season. Rainfall and temperature combined are positively correlated to the total number of captured amphibians. However, individually, rainfall was not significantly correlated, while temperature was positively correlated with the amphibian abundance. Water storage capacity by bromeliads was correlated to characteristics and size of the plant. In the rainy season, the height of the plant and the diameter on top view were correlated with the occurrence of amphibians, while during the driest period there was no correlation among variables and the bromeliad usage by amphibians. Recorded species were strongly associated to the Atlantic Forest domain. Nevertheless, the occupation of rocky seashores by anurans may be more associated with the specialized reproductive modes presented by species, since there is no permanent water available in ponds or streams.
\end{abstract}

Keywords: Alcantarea glaziouana, bromeliacea, climatic variables, inselbergs, Serra da Tiririca.

\section{Seleção de hábitat por uma comunidade de anuros em um costão rochoso na Mata Atlântica costeira, sudeste do Brasil}

\section{Resumo}

Costões rochosos são morros graníticos distribuídos ao longo da costa do sudeste brasileiro, com vegetação xeromórfica devido ao seu solo raso. O conhecimento sobre comunidades de anfíbios e seus padrões reprodutivos é especialmente reduzido neste tipo de ambiente. Neste estudo, nós apresentamos os resultados de dois anos de monitoramento de uma comunidade de anfíbios em um costão rochoso localizado na área protegida do Parque Estadual da Serra da Tiririca, município de Niterói, estado do Rio de Janeiro, Brasil. Nós fizemos buscas diurnas e noturnas para encontrar anuros em bromélias-tanque, superfície rochosa e vegetação arbustiva. O padrão anual de atividade reprodutiva também foi estimado. Indivíduos da bromélia-tanque mais abundante no local, Alcantarea glaziouana, foram coletados e tiveram diversas variáveis mensuradas a fim de se entender a seleção de bromélias por anuros. Verificamos a influência das condições ambientais sobre a abundância dos anfíbios, e a associação entre as medidas 
das bromélias e a capacidade de estocar água no seu tanque. Diferenças na utilização de microhábitats e na ocupação de bromélias pelos anuros também foram investigadas, assim como também foi testada a influência das variáveis das bromélias sobre a ocorrência dos anuros nestas plantas. Foram registradas as seguintes espécies: Scinax aff. $x$-signatus; S. cuspidatus; S. littoreus; Thoropa miliaris e Gastrotheca sp. As bromélias foram o habitat preferido pelos anuros. O hábito noturno foi predominante para todas as espécies. Durante buscas diurnas, os espécimes foram encontrados abrigados nas axilas das folhas das bromélias. O número de machos vocalizando, assim como a abundância de anfíbios, foi associado com o período mais quente e chuvoso. Machos adultos de T. miliaris foram observados vocalizando especialmente na estação chuvosa. A precipitação e a temperatura combinadas foram positivamente correlacionadas com o número total de anfíbios capturados. Entretanto, individualmente, a precipitação não foi significativamente correlacionada, enquanto que a temperatura foi positivamente correlacionada com a abundância de anfíbios. A capacidade de armazenamento de água pelas bromélias está correlacionada com as características e tamanho da planta. Na estação chuvosa, a altura da planta e o seu diâmetro foram correlacionados com a ocorrência de anfíbios, enquanto que durante o período seco não existiu correlação entre variáveis e o uso da bromélia pelos anfíbios. As espécies registradas estão fortemente associadas ao domínio da Floresta Atlântica. Entretanto, a ocupação dos costões rochosos por anuros pode estar mais associado com modos reprodutivos especializados apresentados pelas espécies, já que não existem riachos ou poças d'água permanentes disponíveis no local.

Palavras-chave: Alcantarea glaziouana, bromeliácea, variáveis climáticas, inselbergs, Serra da Tiririca.

\section{Introduction}

The Atlantic Forest biome originally corresponds to a narrow strip along the Brazilian east coast covering about 1.1 million $\mathrm{km}^{2}$ including adjacent areas of Argentina and Paraguay (Mori, 1981; Myers et al., 2000; Mittermeier et al., 2005). This biome presents a wide variety of vegetation, topography and climate conditions (Rizzini, 1979; Veloso et al., 1991; Morellato and Haddad, 2000).

Despite this variety, studies on amphibian communities in this biome have been unbalanced in their approaches, field methods, meticulousness, and research designs (e.g., Bernarde et al., 1999; Giaretta et al., 1999; Eterovick and Sazima, 2000). Studies have being done focused mainly in lentic habitats (e.g. Pombal, 1997; Vasconcelos and Rossa-Feres, 2005), forested areas (e.g., Almeida-Gomes et al., 2008; Salles et al., 2009; Siqueira et al., 2009; Silva-Soares et al., 2010) and, more recently, in restinga formations (e.g., Schneider and Teixeira, 2001; Van Sluys et al., 2004; Rocha et al., 2008; Silva et al., 2008).

Notwithstanding, our knowledge on amphibian communities and their reproductive patterns in Atlantic Forest are reduced (Bertoluci, 1998), especially on rocky seashores. These formations are distributed along southeastern coast of Brazil at latitudes of Rio de Janeiro state and are composed by low rounded granitic hills (inselbergs) with xeric-like vegetation, bromeliads and cactuses. It generally sinks directly into the ocean or presents a narrow lowland area separating it from de coast (Pontes, 1987; Veloso et al., 1991; Ab'Saber, 2003; Barros, 2008). Studies conducted at these formations are limited to species lists lacking data on ecology or natural history in a more complex context (Santos and Sylvestre, 2006; Alves-Silva and Silva, 2009). Herein, we present the results of two years survey assaying the influence of environmental conditions, microhabitat usage and seasonality on anurofauna at Pedra de Itacoatiara, a rocky seashore in Southeastern coast of Brazil.

\section{Material and Methods}

\subsection{Study area}

The study was conducted at Pedra de Itacoatiara rocky seashore (22॰58'39.56” S; 4301'39.93” W; SAD $69)$ located at the oceanic portion of Niterói municipality, Rio de Janeiro state, Southeastern Brazil (Figure 1). The area is a low rounded granitic hill (218 $\mathrm{m}$ a.s.l.) where the accumulation of organic material allows the presence of sparse vegetation (xeric-like) and bryophytes due the shallow soil (Barros and Seoane, 1999). Shrub vegetation composed by bushes, bromeliads, orchids and cactuses are also part of this landscape, although it is dominated by exposed rocks (Pontes, 1987; Santos and Sylvestre, 2006). The study area is inserted in a protected area named Parque Estadual da Serra da Tiririca (PESET) with 2262 ha.

The climate is $A w$ (Bernardes, 1952), being hot and humid having a dry and a rainy season with annual average temperature ranging from $22{ }^{\circ} \mathrm{C}$ to $23{ }^{\circ} \mathrm{C}$ (Coelho, 1988; Barbiére and Coe-Neto, 1999; Kottek et al., 2006) and reaching the maximum of $50{ }^{\circ} \mathrm{C}$ on exposed rocks during the day (Pontes, 1987). The dry season corresponds the months from May to June and the rainy season begins in September, reaching the highest rainfall averages during the months of December and January with annual average of $2137.5 \mathrm{~mm}$ (Nimer, 1989; Barbiére and Coe-Neto, 1999; INMET, 2011).

\subsection{Data collection}

Fieldwork was conducted from August 2008 to July 2010 almost monthly. Visual encounter survey (VES) (Crump and Scott, 1994) was used as sampling method with diurnal and nocturnal searches. Diurnal searches were divided into two periods: matutinal transect (8:00 am to $10: 00 \mathrm{am})$ and crepuscular transects $(3: 00 \mathrm{pm}$ to 


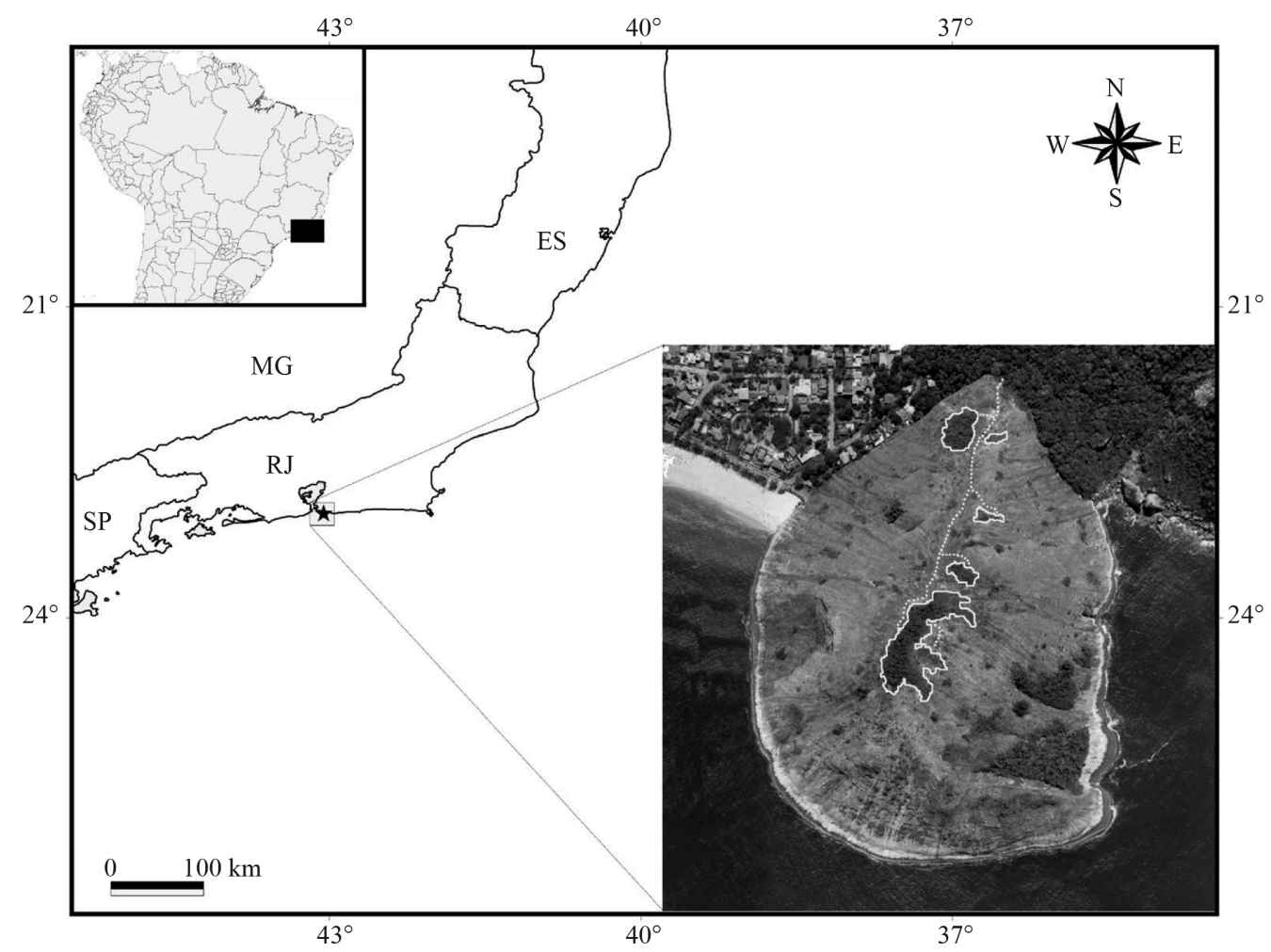

Figure 1 - Location of study area Pedra de Itacoatiara, Niterói, RJ, Southeastern Brazil. Dotted white lines mark transects and solid white lines mark the investigated fragments.

5:00 pm). During the diurnal period, a team of three researchers investigated tank-bromeliads on the ground, rocky surfaces or cracks and in shrubby vegetation seeking for sheltered amphibians. We performed $140 \mathrm{man} /$ hours of diurnal sampling effort being $70 \mathrm{man} /$ hours in the matutinal period and $70 \mathrm{man} /$ hours in the crepuscular period). During the night (6:00 pm to midnight) the same researchers looked for amphibians in aforementioned microhabitats. Each night resulted in $12 \mathrm{man} /$ hours of sampling effort, totaling $144 \mathrm{man} /$ hours of nocturnal searches. The combined sampling effort performed, including diurnal and nocturnal searches, totaled 18 field expeditions and $284 \mathrm{man} /$ hours.

The microhabitat usage was assessed for all observed frogs. Assuming the heterogeneity of the study area, the habitat was divided into categories: tank-bromeliads, rocky surface and shrubby vegetation. After spotted, each amphibian was captured manually and kept in plastic bags with moist leaf or water. To avoid the individuals recount, captured frogs during transects were released nearby the same area at the end of the day or transported to the laboratory, as voucher specimens, where they were euthanized and fixed according to the standard methods (McDiarmid, 1994).

To determine annual patterns of breeding activity of anurans, we estimated the number of calling males during the night, following the classes proposed by Bertoluci (1998) at the whole study site: (1) 1-2 ind., (2) 3-5 ind.,
(3) 6-10 ind., (4) 11-20 ind., (5) 21-50 ind. and (6) more than 50 ind.. Amplectant pairs, egg clutches and gravid females were also recorded as breeding evidence (Bertoluci, 1998).

To understanding the selection of bromeliads by frogs, forty eight specimens of the most abundant tankbromeliad Alcantarea glaziouana (Lemaire) Leme were collected and investigated (24 during the rainy and 24 in the dry season). The collected bromeliads varied widely in size and were measured according to several variables. Prior to collection, we took the following measures in field: (1) major diameter on top view and (MDTV); (2) maximum height of the plant (MH). After collecting field data, these bromeliads were kept in a plastic bag and transported to the laboratory where we measured: (3) major width of the leaf (MWL); (4) number of green leaves (NGL); (5) maximum depth of water tank (MDWT); (6) volume of water in the tank (VWT); (7) maximum storage capacity of the water tank (MSWT); (8) wet weight (WW) and (9) dry weight (DW). We used a $200 \mathrm{~cm}$ metal ruler (precision of $0.5 \mathrm{~cm}$ ) to length measures and a $2000 \mathrm{~mL}$ graduated cylinder (precision of $1.0 \mathrm{~mL}$ ) to measure water volume. Maximum water volume stored by a bromeliad was measured by filling the tank of the specimen with water, using a graduated cylinder, till water began to overflow. After, we removed carefully the leaves and collected all animals inside; we measured wet and dry weight of the bromeliads using a digital scale 
(precision of $0.1 \mathrm{~g}$ ). Dry weight was considered when it stabilizes at $150{ }^{\circ} \mathrm{C}$ (Table 1).

Voucher specimens of amphibians were deposited at the collection of amphibians in Department of Vertebrates of Museu Nacional - UFRJ and voucher specimens of bromeliads were deposited at Herbarium of FFP/UERJ. Licenses for the scientific activities were issued by Sistema de Autorização e Informação em Biodiversidade, SISBIO; Instituto Brasileiro do Meio Ambiente e dos Recursos Renováveis, IBAMA ( ${ }^{\circ}$ 088/2004, $\mathrm{n}^{\mathrm{o}}$ 20385-1 and $\left.\mathrm{n}^{\mathrm{o}} 110 / 2005\right)$ and Instituto Estadual do Ambiente, INEA ( ${ }^{\circ} 002 / 2010 n^{\circ} 013 / 05$, proc. E07/300039/2005).

In order to complement our survey, we assessed information of environmental conditions. Air temperature was measured at the beginning and at the end of transects with a thermometer (precision of $0.2{ }^{\circ} \mathrm{C}$ ) being considered the average between both. Data on rainfall were obtained from a meteorological station belonging to Instituto Nacional de Meteorologia (INMET) at Forte de Copacabana, municipality of Rio de Janeiro. This station is distant about $10 \mathrm{~km}$ from the study area $\left(22^{\circ} 57^{\prime} 06.9^{\prime \prime}\right.$ $\mathrm{S} ; 4^{\circ} 11^{\prime} 55.8^{\prime \prime} \mathrm{W}$; SAD 69), thus exposed to similar climatic conditions (Figure 2).

\subsection{Data analysis}

Simple linear regression analysis was performed to compare how similar were the sample period and available data on climatic conditions of the previous decades (1961 to 2007). To check the influence of the environmental conditions on amphibian abundance we used multiple regression including environmental variables (temperature and rainfall averages), abundances per species and total abundance (Zar, 1999).
Concerning the bromeliads, multiple regressions were applied to test if there is association between the measures taken from bromeliads and the water storage in the tank. We also applied chi-square tests to check if microhabitat usage and bromeliad occupancy by frogs differs statistically. We test the influence of the bromeliad variables on the occurrence of amphibians in the bromeliads performing multiple regressions using amphibian abundance as the dependent variable. We used a significance index of $\mathrm{p}<0.05$ for all analyses. All variables were natural log transformed and the normality was tested applying Kolmogorov-Smirnov analysis (Zar, 1999).

\section{Results}

Our survey revealed the presence of only five species of anurans in the rocky seashore. It resulted in collection/observation of 416 individuals. Hylidae was the most representative family (Scinax aff. $x$-signatus; $S$. cuspidatus Lutz, 1925 and S. littoreus Peixoto, 1988) followed by Cycloramphidae (Thoropa miliaris Spix, 1824) and Hemiphractidae (Gastrotheca sp.). During the study (including night and day transects) the amphibian abundance recorded was $1.7 \mathrm{ind} . / \mathrm{h}$. Scinax littoreus was the most abundant species $(\mathrm{N}=299$ or $72 \%)$, followed by $T$. miliaris $(\mathrm{N}=107$ or $25.8 \%)$; S. cuspidatus $(\mathrm{N}=8$ or $2 \%)$, Gastrotheca sp. and $S$. aff. $x$-signatus (both with $\mathrm{N}=1$ or $0.2 \%)$.

According to chi-square tests, bromeliads were the preferential habitat used by anurans $(\mathrm{N}=306$ or $73.6 \%)\left(\chi^{2}=33.97 ; \mathrm{p}=0.05 ; \mathrm{df}=1\right.$ for bromeliads $\mathrm{x}$ rocky surfaces and $\chi^{2}=105.9 ; \mathrm{p}=0.05 ; \mathrm{df}=1$ bromeliads $x$ shrubby vegetation). The matrix composed by exposed rocks and bryophytes was the second most

Table 1 - Bromeliads (Alcantarea glaziouana) variables gathered at Pedra de Itacoatiara: MDTV (major diameter on top view); MH (maximum height of the plant); MWL (major width of the leaf); NGL (number of green leaves); MDWT (maximum depth of water tank); VWT (volume of water in the tank); MSWT (maximum storage capacity of the water tank); WW (wet weight) and DW (dry weight)

\begin{tabular}{|c|c|c|c|c|c|c|}
\hline \multirow{3}{*}{ Bromeliads measures } & \multicolumn{6}{|c|}{ Seasons } \\
\hline & \multicolumn{3}{|c|}{ Wet } & \multicolumn{3}{|c|}{ Dry } \\
\hline & Mean / SD & Max & Min & Mean / SD & Max & Min \\
\hline $\operatorname{MDTV}(\mathrm{cm})$ & $66.2 \pm 28.3$ & 130 & 30 & $67.2 \pm 20.3$ & 122 & 40 \\
\hline $\mathrm{MH}(\mathrm{cm})$ & $63.8 \pm 17.6$ & 97 & 37 & $65.1 \pm 17.7$ & 135 & 43 \\
\hline MWL (cm) & $14.4 \pm 4.1$ & 25 & 7.5 & $14 \pm 3.3$ & 21 & 9 \\
\hline NGL & $41.1 \pm 16.5$ & 76 & 16 & $35.5 \pm 15.9$ & 95 & 17 \\
\hline MDWT (cm) & $15.4 \pm 3.9$ & 22 & 7 & $15.1 \pm 3.4$ & 23 & 9 \\
\hline VWT (mL) & $672.5 \pm 1161.2$ & 4400 & 0 & $664.2 \pm 574.1$ & 2200 & 40 \\
\hline MSWT (mL) & $3087.2 \pm 2389.7$ & 9000 & 380 & 2791.52019 .6 & 7300 & 675 \\
\hline WW (g) & $1435.4 \pm 1200.8$ & 4449.3 & 166.1 & $1591.1 \pm 989.5$ & 4243 & 441 \\
\hline DW (g) & $229.9 \pm 220.1$ & 754.1 & 27.8 & $207.1 \pm 168.1$ & 767.5 & 45.8 \\
\hline
\end{tabular}




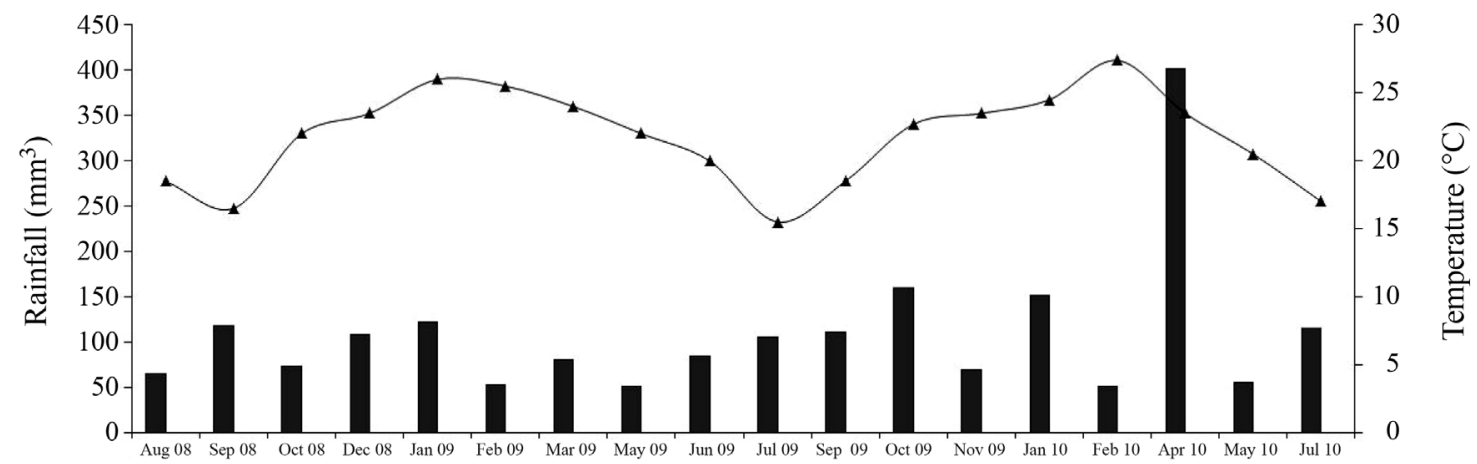

Field expeditions (days)

Figure 2 - Environmental data gathered at Pedra de Itacoatiara, Niterói, RJ, Southearten Brazil during the studied period. Legend: Solid black line with triangles: temperature $\left({ }^{\circ} \mathrm{C}\right)$; solid dark gray bars: rainfall averages $\left(\mathrm{mm}^{3}\right)$.

used habitat ( $\mathrm{N}=98$ or $23.6 \%$ ) and shrubby vegetation was the less microhabitat used by amphibians $(\mathrm{N}=12$ or $2.9 \%$ ).

The nocturnal habit was predominant for all species and the individuals were observed mostly during crepuscular or nocturnal searches ( $\mathrm{N}=372$ or $89.4 \%$ ). At night, most of amphibians were observed on bromeliads leaves $(\mathrm{N}=281$ or $67.5 \%)$, on the surface of the exposed rock $(\mathrm{N}=89$ or $21.4 \%)$ and in the sparse leaf-litter in the shrub vegetation $(\mathrm{N}=12$ or $2.9 \%)$. During diurnal searches the specimens were found sheltered in bromeliads axils $(\mathrm{N}=36$ or $81.8 \%)$, in rocky burrows $(\mathrm{N}=6$ or $13.6 \%)$ or in shrubby vegetation $(\mathrm{N}=2$ or $4.5 \%)$.

Males started to vocalize soon after the sunset and the number of calling males increased during the night. Around 8:00 pm the chorus reached the peak of active males and decreases around 11:00 pm, ceasing up around midnight. The number of calling males as well as amphibian abundance was associated with the rainiest and warmest period of the year. Occasionally, specimens of
S. littoreus were observed vocalizing from bromeliads during cloudy and rainy days $(\mathrm{N}=8)$, especially in the wet season (Figure 3).

Regarding the seasonality, the data allowed us to make inferences on reproductive patterns of $S$. littoreus and T. miliaris. The species $S$. littoreus was observed in breeding activity in the majority of sample period. Adult males were found vocalizing from tank-bromeliad leaves (A. glaziouana) from August to May. Tadpoles and amplectant pairs were observed mostly during the peak of rainy season (October to March) only inside of tankbromeliad A. glaziouana. Adult calling males of $T$. miliaris were observed especially in the rainy season (September to May). Tadpoles and gravid females were observed during the peak of the rainy season (December to February). During the driest months (June to August) any adult or tadpole of T. miliaris was found. Amplectant pairs were not observed for this species during the sample period (Figure 3).

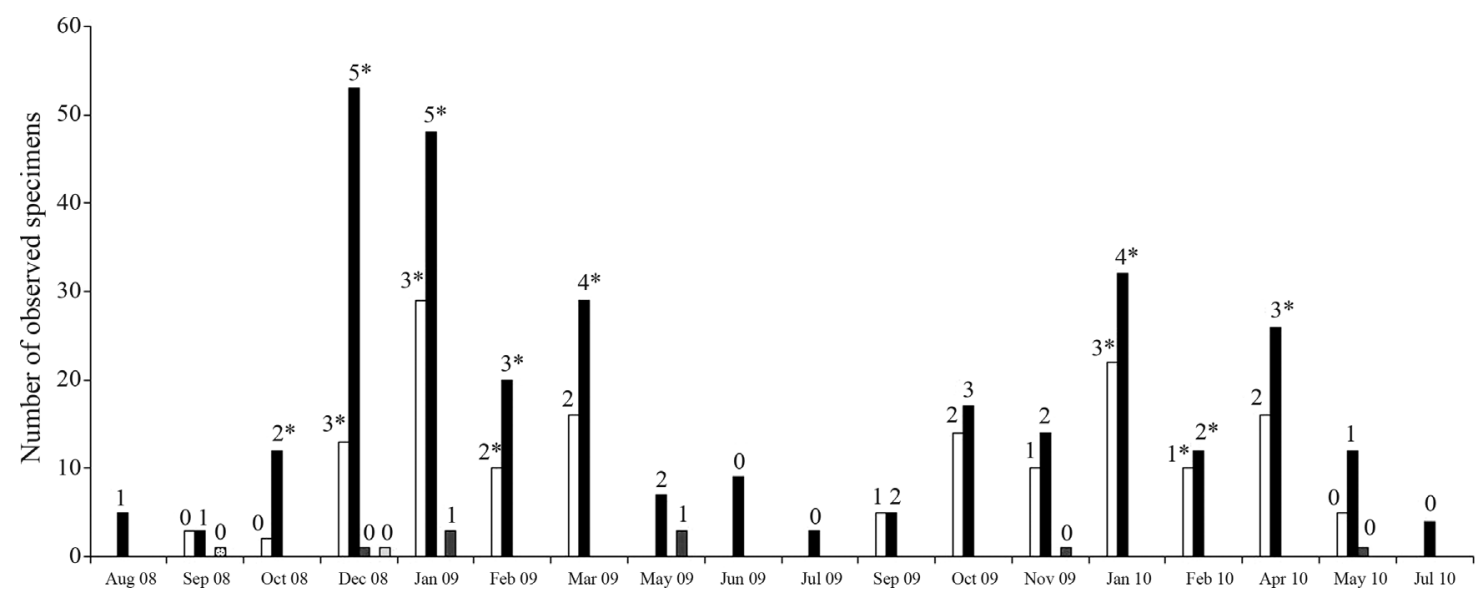

Figure 3 - Amphibian abundance recorded at Pedra de Itacoatiara, Niterói, RJ, Southeastern Brazil from August 2008 to July 2010. Legend: Black bars: Scinax littoreus; White bars: Thoropa miliaris; Dark Gray bars: Scinax cuspidatus; Light gray bars: Scinax aff. $x$-signatus and White bar with black dots: Gastrotheca sp. Numbers represents the classes of calling males and asterics represent recorded breeding evidence. 
According to the simple linear regression, the environmental data gathered during the sample period does not differ statistically from the available data of previous decades $\left(\mathrm{F}_{1,18}=8.09 ; \mathrm{p}=0.05\right.$ for rainfall and $\mathrm{F}_{1,18}=13.55 ; \mathrm{p}<0.01$ for the temperature). Multiple regressions analysis demonstrates that rainfall and temperature combined are positively correlated to the total number of captured amphibians $\left(\mathrm{F}_{6,17}=10.43 ; \mathrm{p}<0.01\right)$. However, individually, rainfall was not significantly correlated $\left(\mathrm{F}_{6,17}=2.31 ; \mathrm{p}>0.05\right)$, while temperature was positively correlated with the amphibian abundance $\left(\mathrm{F}_{6,17}=16.42 ; \mathrm{p}<0.01\right)$.

At the rainy season, bromeliad collected in the field presented mean water volume of $672.5 \pm 1161.2 \mathrm{~mL}$, with a maximum of $4400 \mathrm{~mL}$. During the dry season the mean of this variable was $664.3 \pm 574.1 \mathrm{~mL}$, with a maximum of $2200 \mathrm{~mL}$. The maximum storage capacity of the water tank in the dry season was correlated to the height of the plant $\left(\mathrm{F}_{5,18}=16.2 ; \mathrm{p}<0.05\right)$ and the major width of the leaf $\left(\mathrm{F}_{5,18}=16.2 ; \mathrm{p}<0.01\right)$. Unlike what was observed during the rainy season, the number of green leaves was associated to the maximum water storage in the plant $\left(\mathrm{F}_{4,19}=46.8 ; \mathrm{p}<0.01\right)$.

Regarding the amphibian abundance, A. glaziouana presented 0.5 ind./plant in the rainy season and 0.9 ind./plant during the dry season. The number of occupied bromeliads by frogs $(\mathrm{N}=17$ or $35.4 \%$ ) was not statistical significant when compared to vacant bromeliads $(\mathrm{N}=31$ or $64.6 \%)\left(\chi^{2}=3.34 ; \mathrm{p}=0.05 ; \mathrm{df}=1\right)$. Multiple regressions analysis revealed that in the rainy season the height of the plant $\left(\mathrm{F}_{5,18}=6.8 ; \mathrm{p}<0.05\right)$ and the diameter on top view $\left(\mathrm{F}_{5,18}=6.8 ; \mathrm{p}<0.05\right)$ were correlated with the occurrence of amphibians inside of bromeliads. The same analysis indicated that during the driest period there is no correlation among variables and the bromeliad usage by amphibians.

\section{Discussion}

The community structure and species composition on rocky seashores, in general, differ from the surrounding forested areas (Meirelles et al., 1999; Porembski and Barthlott, 2000; Santos and Sylvestre, 2006). Similarly, the anurofauna that inhabits the rocky seashores is different from those found at the lowland surrounding areas (RC Pontes personal observation). Comparing our data with other reported anurofauna on bromeliads from closer sites, the studied area present low species similarity with restinga of Maricá (Silva et al., 1988, 2011), nearby $16 \mathrm{~km}$ from our study site. However, the species composition at restinga environments is more similar to lowland ombrophilous areas due to their proximity (Carvalho-e-Silva et al., 2000). Probably, amphibian composition observed at rocky seashore is more similar to isolated marine and coastal granitic island. Such habitats, resembles rocky seashores environments presenting large areas of exposed rocks, bromeliads fields and sparse vegetation where several species of Hylidae and Cycloramphidae were recently described (e.g., Brasileiro et al., 2007a - Scinax faivovich; 2007b - S. peixotoi; $2007 \mathrm{c}$ - Cycloramphus faustoi). Despite the similarity of the reproductive modes among island-dweller species and rocky seashore-dweller species, we lack long term studies on insular amphibian community for further comparisons.

Recorded species are strongly associated to the Atlantic Forest domain (sensu Heyer et al., 1990) and the predominance of Hylidae species in amphibian communities was a tendency observed by many authors in different studied sites at Neotropical region (Duellman, 1978; Bertoluci, 1998). Such pattern has been associated to the presence of adhesive discs allowing the occupation of vertical strata by different species, mainly in lentic habitats (Cardoso et al., 1989; Pombal, 1997; Prado and Pombal, 2005). However, the occupation of rocky seashores by anurans may be more associated with the specialized reproductive modes presented by species, since there is no permanent water available in ponds or streams. Scinax littoreus is a bromeligenous species (sensu Peixoto, 1995) and have their whole complex life cycle associated to the bromeliads (Alves-Silva and Silva, 2009). Also, the species T. miliaris is adapted to breed in temporary water films that flow over the rocks after rains where it tadpole grows and metamorphoses into a froglet (Giaretta and Facure, 2004; Haddad and Prado, 2005). Thus, these species reduced the dependence of great water collections for reproduction. On the other hand, other species reported here for rocky seashore are considered as bromelicolous species (sensu Peixoto, 1995), using these plants as diurnal shelter only, once their reproduction (probably except for Gastrotheca sp.) is associated to swampy areas.

Among vertebrates, anurans are the most commonly taxa found in association with bromeliads (Rocha et al., 2004). These plants are important for these organisms, especially in areas under hydric stress (e.g., restingas, rocky seashores), used as shelter or breeding site (Lehtinen et al., 2004; Silva et al., 2011). Due to the lack of water bodies at rocky seashore, bromeliads proved to be important habitats for amphibians. Silva et al. (2011) reported $S$. cuspidatus and $S$. littoreus using bromeliads in restinga de Maricá, Rio de Janeiro state, Brazil. Bromeliad usage by adult specimens of T. miliaris was also reported in rocky outcrop in Atlantic Forest of Minas Gerais state (Lacerda et al., 2009) and Espiríto Santo state (Teixeira et al., 2006; Teixeira and Rödder, 2007). Despite these records, T. miliaris still considered as a bromelicolous species since no tadpoles or egg clutch were found inside bromeliads. So far, only a few studies have been published on amphibians using bromeliads, however most of these studies were descriptive and focused in restinga formations (e.g., Silva et al., 1988; Teixeira et al., 1997; Silva et al., 2011) or Atlantic Forest areas (Schneider and Teixeira, 2001; Pertel et al., 2006; Lacerda et al., 2009). Thus, we lack information on amphibians from rocky seashores for comparisons.

The matrix composed by exposed rocky surfaces and sparse leaf litter in shrubby vegetation is the most com- 
mon habitat at Pedra de Itacoatiara, although it was used frequently only by $T$. miliaris. This species is being commonly associated to these types of habitats (Rocha et al., 2002; Giaretta and Facure, 2004). Sparse vegetation composed by shrubs and small trees was the less used microhabitat by amphibians. Considering the high temperatures and the direct incidence of sun during the day, such habitats may not figure as the most suitable for amphibians, being used sporadically.

Considering the total number of anurans per bromeliad, our results were similar to those reported by Silva et al. (2011) (1.04 ind./plant) for restinga de Maricá. Among the surveyed bromeliads $35.4 \%$ were occupied by anurans and $64.6 \%$ were vacant, which represents a lower density of anurans than observed for restinga de Maricá ( $42.0 \%$ occupied and $58.0 \%$ vacant). Nevertheless, we attribute the higher species richness and amphibian density per bromeliad at restinga de Maricá due to the presence of a variety of habitats (e.g., temporary ponds) unlike the surveyed area in the present study. Those habitats are used by many specimens of anurans for reproduction (Almeida-Gomes et al., 2010) and during the day or the driest months such anurans could shelter inside bromeliads.

Several species of Scinax perpusillus species group are selective in the choice of bromeliad for reproduction (Oliveira and Novaes, 2004; Alves-Silva and Silva, 2009; Silva et al., 2011; Silva and Alves-Silva, 2011). At restinga of Maricá municipality (distant ca $16 \mathrm{~km}$ ) the species $S$. littoreus was cited as occasional (Silva et al., 2011). Notwithstanding, this species was ranked as the most abundant during the sample period in our study area. Moreover, Neoregelia cruenta (Grahan) L.B. Smith is the predominant bromeliad at Maricá restinga and probably the experienced conditions in this bromeliad at this site does not figure as suitable for laying eggs by this frog (Silva et al., 2011). At Pedra de Itacoatiara, a large population of tank-bromeliad A. glaziouana is established (Barbará et al., 2009) (misnamed as $A$. imperialis by Alves-Silva and Silva, 2009 and Silva et al., 2011) and these plants could storage large amounts of water during the whole year. The water storage capacity, associated with chemical conditions of the water probably plays an important role in the choice of the plants by these frogs (Silva et al., 2011), whereas several individuals of $N$. cruenta and Vriesea neoglutinosa Mez. were also observed at study site but no individual of $S$. littoreus was observed using this species as breeding site.

At boreal and austral zones the seasonality is strongly marked and temperature is an important abiotic factor on the amphibian reproduction (Duellman and Trueb, 1994; Pombal, 1997). Unlike, at Neotropical sites seasonality is less marked (Crump, 1974) and the rainfall rates plays the major role on amphibian reproduction (Cardoso and Martins, 1987; Pombal, 1997). On rocky seashores, due to the scarcity of water, both factors may influence the species abundance and reproduction. The species $T$. miliaris fits into the classification summer species with a shorter breeding season (sensu Bertoluci, 1998). Despite several specimens observed vocalizing on exposed rocks from September to May, tadpoles and gravid females were observed only in the rainiest months (December, January and February). A similar pattern was observed for $S$. littoreus. This species could extended its breeding season from August to May but tadpoles, amplectant pairs and egg clutches were observed only from October to March. Males vocalized almost during the whole year, except for the months of June and July. According to the gathered data, summer species with longer breeding season is the classification proposed for S. littoreus (sensu Bertoluci, 1998).

This study represents a framework of a rocky seashore amphibian community. The approach used is mainly descriptive and the knowledge on these communities is still reduced due the lack of studies. Probably, other environmental factors (e.g., wind speed, moon phase, humidity and chemical conditions of the watertank) are influencing aspects as breeding season, spatial and temporal distribution or number of calling males of amphibian species. Observations indicated a reduction of vocalization by anurans during full moon. Furthermore, in windy nights the same condition was observed. Nevertheless, more long-term studies on amphibian's community in rocky seashores approaching these variables must be conducted to improve our comprehension of the relations between amphibians and bromeliads in these habitats.

\section{Material Examined}

Brazil: Rio de Janeiro State: Niterói Municipality: Pedra de Itacoatiara: Scinax littoreus: MNRJ 59641-46; MNRJ 77526; MNRJ 77521; MNRJ 77516-17 and MNRJ 77521. Thoropa miliaris: MNRJ 58531-44. Scinax cuspidatus: MNRJ 57522-23. Gastrotheca sp.: MNRJ 53591. Scinax aff. eurydice: MNRJ 53594-95.

\section{Acknowledgments}

We would like to thank the members of Setor de Herpetologia of Museu Nacional/UFRJ and all others who supported us in fieldwork and for identification of the specimens. R. M. Silveira and R. Moura for the help in field work with the bromeliads. The staff of PESET and the surrounding residents for supporting the research. To R.R. Pinto and A.R. Martins for their help in the statistical analysis and valuable comments. To INEA and SISBIO IBAMA for issued the scientific activities and finally to CAPES, CNPq and FAPERJ for the financial support to the authors.

\section{References}

AB'SABER, AN., 2003. Os domínios de natureza no Brasil potencialidades paisagísticas. São Paulo: Ateliê Editorial. $159 \mathrm{p}$.

ALMEIDA-GOMES, M., VRCIBRADIC, D., SIQUEIRA, CC., KIERFER, MC., KLAION, T., ALMEIDA-SANTOS, P., NASCIMENTO, D., ARIANI, CV., BORGESJUNIOR, VNT., FREITAS-FILHO, RF., VAN SLUYS, 
M. and ROCHA, CFD., 2008. Herpetofauna of an Atlantic rainforest area (Morro São João) in Rio de Janeiro State, Brazil. Anais da Academia Brasileira de Ciências, vol. 2 , no. 80, p. 1-10.

ALMEIDA-GOMES, M., ALMEIDA-SANTOS, M., GOYANNES-ARAÚJO, P., BORGES-JÚNIOR, VNT., VRCIBRADIC, D., SIQUEIRA, CC., ARIANI, CV., DIAS, AS., SOUZA, VV., PINTO, RR., VAN SLUYS, M. and ROCHA, CFD., 2010. Anurofauna of an Atlantic Rainforest fragment and its surroundings in Northern Rio de Janeiro State, Brazil. Brazilian Journal of Biology, vol. 70, no. 3, p. 871-877.

ALVES-SILVA, R. and SILVA, HR., 2009. Life in bromeliads: reproductive behaviour and the monophyly of the Scinax perpusillus species group (Anura: Hylidae). Journal of Natural History, vol. 43, no. 3, p. 205-217.

BARBARÁ, T., MARTINELLI G., PALMA-SILVA, C., FAY, MF., MAYO S. and LEXER C., 2009. Genetic relationships and variation in reproductive strategies in four closely related bromeliads adapted to neotropical 'inselbergs': Alcantarea glaziouana, A. regina, A. geniculate and A. imperialis (Bromeliacea). Annals of Botany, vol. 103, p. 65-77.

BARBIÉRE, EB. and COE-NETO, R., 1999. Spatial and temporal variation of the east fluminense coast and atlantic Serra do Mar, State of Rio de Janeiro, Brazil. In KNOPPERS, BA., BIDONE, ED. and ABRÃO, JJ., (Eds.). Environmental geochemistry of Coastal Lagoon systems of Rio de Janeiro, Brazil. Niteroi: Universidade Federal Fluminense. p. 47-56. Série Geoquímica Ambiental, no. 5.

BARROS, AAM., 2008. Análise florística e estrutural do Parque Estadual da Serra da Tiririca, Niterói E Maricá, RJ, Brasil. Rio de janeiro: Escola Nacional de Botânica Tropical, Instituto de Pesquisas Jardim Botânico do Rio de Janeiro. 237 p. Tese de Doutorado.

BARROS, AAM. and SEOANE, CES., 1999. A problemática da conservação do Parque Estadual da Serra da Tiririca, Niterói / Maricá, RJ, Brasil. In VALLEJO, LR. and SILVA, MTC. (Eds.). Os (Des) Caminhos do Estado do Rio de Janeiro Rumo ao Século XXI. Niterói: Instituto de Geociências da UFF. p. 114-124.

BERNADE PS., KOKOBUM MNC., MACHADO RS. and ANJOS L., 1999. Uso de habitats naturais e antrópicos pelos anuros em uma localidade no Estado de Rondônia, Brasil (Amphibia: Anura). Acta Amazônica, vol. 29, p. 555-562.

BERNARDES, LMC., 1952. Tipos de clima do Estado do Rio de Janeiro. Revista Brasileira de Geografia, vol. 14, p. $57-80$.

BERTOLUCI, J., 1998. Annual patterns of breeding activity in Atlantic Rainforest anurans. Journal of Herpetology, vol. 32 , no. 4, p. 607-611.

BRASILEIRO, CA., OYAMAGUCHI, HM. and HADDAD, CFB., 2007a. A new island species of Scinax (Anura; Hylidae) from southeastern Brazil. Journal of Herpetology, vol. 41, no. 2, p. 271-275.

BRASILEIRO, CA., HADDAD, CFB., SAWAYA, RJ. and MARTINS, M., 2007b. A new and threatened species of Scinax (Anura: Hylidae) from Queimada Grande Island, southeastern Brazil. Zootaxa, vol. 1391, p. 47-55.

BRASILEIRO, CA., HADDAD, CFB., SAWAYA, RJ. and SAZIMA, I., 2007c. A new and threatened island-dwelling species of Cycloramphus (Anura: Cycloramphidae) from southeastern Brazil. Herpetologica, vol. 63, no. 4, p. $501-510$.
CARDOSO, AJ. and MARTINS, JE., 1987. Diversidade de anuros durante o turno de vocalização em comunidades neotropicais. Papéis Avulsos de Zoologia, vol. 36, p. 279-285.

CARDOSO, AJ., ANDRADE, GV. and HADDAD, CFB., 1989. Distribuição espacial em comunidades de anfíbios (Anura) no sudeste do Brasil. Revista Brasileira de Biologia, vol. 49, p. 241-249.

CARVALHO-E-SILVA, SP., IZECKSOHN, E. and CARVALHO-E-SILVA, AMPT., 2000. Diversidade e ecologia de anfíbios em restingas do sudeste brasileiro. In ESTEVES, FA. and LACERDA, LD. (Eds.). Ecologia de Restingas e Lagoas costeiras. Macaé, Rio de Janeiro: NUPEM/UFRJ. p. 89-97.

COELHO, GWC., 1988. Observações gerais sobre o clima, solo e hidrografia do Município de Niterói, RJ. Niterói: IDURB - Secretaria de Urbanismo e Meio Ambiente. $14 \mathrm{p}$.

CRUMP, ML., 1974. Reproductive strategies in a tropical anuran community. Miscelanious Publications in Natural History of University of Kansas, vol. 61, p. 1-68

CRUMP, ML. and SCOTT-JR, NJ., 1994. Visual encounter surveys. In HEYER, WR., DONNELLY, MA., MCDIARMID, RW., HAYEK, LAC. and FOSTER, MS. (Eds.). Measuring and monitoring biological diversity. Standard methods for amphibians. Washington: Smithsonian Institution Press. p. 84-92.

DUELLMAN, WE., 1978. Patterns of species diversity in anuran amphibians in the American Tropics. Annals of the Missouri Botanical Garden, vol. 75, p. 79-104.

DUELLMAN, WE. and TRUEB, L., 1994. Biology of amphibians. New York: McGraw-Hill, $670 \mathrm{p}$

ETEROVICK, PC. and SAZIMA, I., 2000. Structure of an anuran community in a montane meadow in southeastern Brazil: effects of seasonality, habitat and predation. Amphibia-Reptilia, vol. 21, p. 439-461.

GIARETTA, AA., FACURE, KG., SAWAYA, RJ., MEYER, JHM. and CHEMIN, N., 1999. Diversity and abundance of litter frogs in a montane forest of Southeastern Brazil: seasonal and altitudinal changes. Biotropica, vol. 31, p. 669-674.

GIARETTA, AA. and FACURE, KG., 2004. Reproductive ecology and behavior of Thoropa miliaris (Spix, 1824) (Anura, Leptodactylidae, Telmatobiinae). Biota Neotropical, vol. 4, no. 2, p. 1-10.

HADDAD, CFB. and PRADO, CRA., 2005. Reproductive modes in frogs and their unexpected diversity in the Atlantic Forest of Brazil. BioScience, vol. 3, no. 55, p. 207-217.

HEYER, WR., RAND, AS., CRUZ, CAG., PEIXOTO, O. and NELSON, CE., 1990. Frogs of Boracéia. Arquivos de zoologia, vol. 31, p. 231-410.

INSTITUTO NACIONAL DE METEOROLOGIA - INMET., 2011. Available from http://www.inmet.gov.br/. Acessed in Oct. 23, 2011.

KOTTEK, M., GRIESER, J., BECK, C., RUDOLF, B. and RUBELF, F., 2006. World map of the Köppen-Geiger climate classification updated. Meteorologische Zeitschrift, vol. 15 , p. 259-263.

LACERDA, JVA., ASSIS, B., SANTANA, DJ. and FEIO, RN., 2009. Anurans in bromeliads, Parque Estadual da Serra do Brigadeiro, state of Minas Gerais, southeastern Brazil. Checklist, vol. 5, no. 4, p. 800-806.

LEHTINEN, RM., LANOO, MJ. and WASSERSUG, RJ., 2004. Phytotelm-breeding anurans: past, present, and future research; In LEHTINEN, RM. (Ed.). Ecology and evolution 
of phytotelm-breeding anurans. Ann Arbor: University of Michigan. p. 1-9. Miscellaneous Publications of the Museum of Zoology, no. 193.

McDIARMID, RW., 1994. Preparing amphibians as scientific specimens. In: HEYER, WR., DONNELLY, MA., MCDIARMID, RW., HAYEK, LAC. and FOSTER, MS (Eds.). Measuring and monitoring biological diversity. Standard methods for amphibians. Washington: Smithsonian Institution Press. p. 289-297.

MEIRELLES, ST., PIVELLO, VR. and JOLY, CA., 1999. The vegetation of granite rock outcrops in Rio de Janeiro, Brazil, and the need for its protection. Environmental Conservation, vol. 26, p. 10-20.

MITTERMEIER, RA., GIL, PR, HOFFMAN, M., PILGRIM, J., BROOKS, T., MITTERMEIER, CG., LAMOREUX, J. and FONSECA, GAB., 2005. Hotspots revisited: Earth's biologically richest and most endangered terrestrial ecoregions. Chicago: University Chicago Press; Conservation International. $432 \mathrm{p}$.

MORELLATO, LPC. and HADDAD, CFB., 2000. Introduction: the Brazilian Atlantic Forest. Biotropica, vol. 32, no. 4b, p. 786-792.

MORI, SA., 1981. Distribution patterns and conservation of eastern Brazilian coastal forest trees species. Brittonia, vol. 33 , no. 2 , p. $233-245$

MYERS, N., MITTERMEIER, RA., MITTERMEIER, CG., FONSECA, GAB. and KENT J., 2000. Biodiversity hotspots for conservation priorities. Nature, vol. 403, p. 853-845.

NIMER, E., 1989. Climatologia no Brasil. Rio de Janeiro: IBGE. $421 \mathrm{p}$.

OLIVEIRA, FB. and NOVAES, CA., 2004. Plant selection and seasonal patterns of vocal activity in two populations of the bromeligen treefrog Scinax perpusillus (Anura, Hylidae). Journal of Herpetology, vol. 38, p. 331-339.

PEIXOTO, OL., 1995. Associação de anuros a bromeliáceas na Mata Atlântica. Revista da Universidade Rural: Série Ciências da Vida, vol. 17, no. 2, p. 75-83.

PERTEL, W., TEIXEIRA, RL. and RÖDDER, D., 2006. Anurans inhabiting soil Bromeliads in Santa Teresa, southeastern Brazil. Amphibia, vol. 5, no. 2, p. 16-19.

POMBAL JR, JP., 1997. Distribuição espacial e temporal de anuros (Amphibia) em uma poça permanente na Serra de Paranapiacaba, sudeste do Brasil. Revista Brasileira de Biologia, vol. 57, no. 4, p. 583-594.

PONTES, JAL., 1987. Serra da Tiririca, RJ. Necessidade de conservação ( $1^{\mathrm{a}}$ Contribuição). Boletim FBCN, vol. 22, p. 89-94.

POREMBSKI, S. and BARTHLOTT, W., 2000. Granitic and gneissic outcrops (inselbergs) as centers of diversity for desiccation-tolerant vascular plants. Plant Ecology, vol. 151, p. 19-28.

PRADO, GM. and POMBAL JR, JP., 2005. Distribuição espacial e temporal dos anuros em um brejo da Reserva Biológica de Duas Bocas, sudeste do Brasil. Arquivos do Museu Nacional, vol. 63, no. 4, p. 685-705.

RIZZINI, CT., 1979. Tratado de fitogeografia do Brasil - aspectos sociológicos e florísticos. São Paulo: HUCITEC; EDUSP. 374 p. vol. 2

ROCHA, CFD., VAN SLUYS, M., BERGALLO, HG. and ALVES, MA., 2002. Microhabitat use and orientation to water flow direction by tadpoles of the leptodactylid frog Thoropa miliaris in Southeastern Brazil. Journal of herpetology, vol. 36, no. 1, p. 100-106.

ROCHA, CFD., COGLIATTI-CARVALHO, L., NUNESFREITAS, AF., ROCHA-PESSOA, TC., DIAS, AS.
ARIANI, CV. AND MORGADO, LN., 2004. Conservando uma larga porção da diversidade biológica através da conservação de Bromeliaceae. Vidalia, vol. 2, no. 1, p. 52-72.

ROCHA, CFD., HATANO, FH., VRCIBRADIC, D. and VAN SLUYS, M., 2008. Frog species richness, composition and beta-diversity in coastal Brazilian Restinga habitats. Brazilian Journal of Biology, vol. 68, p. 101-107.

SALLES, ROL., WEBER, LN. and SILVA-SOARES, T., 2009. Amphibia, Anura, Parque Natural Municipal da Taquara, municipality of Duque de Caxias, state of Rio de Janeiro, southeastern Brazil. CheckList, vol. 5, no. 4, p. 840-854.

SANTOS, MG. and SYLVESTRE, LS., 2006. Aspectos florísticos e econômicos das pteridófitas de um afloramento rochoso do Estado do Rio de Janeiro, Brasil. Acta Botanica Brasilica, vol. 20, no. 1, p. 115-124.

SCHINEIDER, JAP. and TEIXEIRA, RL., 2001. Relacionamento entre anfíbios anuros e bromélias da Restinga de Regência, Espírito Santo, Brazil. Iheringia: Série Zoologia, vol. 91, p. 41-48.

SILVA, HR., BRITTO-PEREIRA, MC., CARAMASCHI, U. e CERQUEIRA, R., 1988. Utilização de Neoregelia cruenta (Bromeliaceae) como abrigo diurno por anfíbios anuros na Restinga de Maricá, Rio de Janeiro. In Anais do VI Seminário Regional de Ecologia. São Carlos: UFSCar. p. 307-318.

SILVA, HR., CARVALHO, ALG. and BITTENCOURT-SILVA, GB., 2008. Frogs of Marambaia: a naturally isolated Restinga and Atlantic Forest remnant of southeastern Brazil. Biota Neotropical, vol. 8, no. 4, p. 167-174.

SILVA, HR. and ALVES-SILVA, R., 2011. A new bromeligenous species of the Scinax perpusillus group from State of Rio de Janeiro, Brazil (Anura, Hylidae). Zootaxa, vol. 3043, p. 54-68.

SILVA, HR., CARVALHO, ALG. and BITTENCOURT-SILVA, GB., 2011. Selecting a hiding place: anuran diversity and the use of bromeliads in threatened coastal sand dune habitat in Brazil. Biotropica, vol. 43, no. 2, p. 218-227.

SILVA-SOARES, T., HEPP, FS., COSTA, PN., LUNA-DIAS, C., GOMES, MR., CARVALHO-E-SILVA, AMPT. and CARVALHO-E-SILVA, SP., 2010. Anfíbios Anuros da RPPN Campo Escoteiro Geraldo Hugo Nunes, Município de Guapimirim, Rio de Janeiro, Sudeste do Brasil. Biota Neotropical, vol. 10, no. 2 , p. 225-233.

SIQUEIRA, CS., VCIBRADIC, D., ALMEIDA-GOMES, M., BORGES-JUNIOR VNT., ALMEIDA-SANTOS, P., ARIANI, CV., GUEDES, DM., GOYANNES-ARAÚJO, P., DORIGO, TA., VAN SLUYS, M. and ROCHA, CFD., 2009. Density and richness of leaf litter frogs (Amphibia: Anura) of an Atlantic Rainforest area in the Serra dos Órgãos, Rio de Janeiro State, Brazil. Zoologia, vol. 26, no. 1 , p. 97-102.

TEIXEIRA, RL., ZAMPROGNO, C., ALMEIDA, GI. and SCHINEIDER, JAP., 1997. Tópicos ecológicos de Phyllodytes luteolus (Amphibia, Hylidae) da Restinga de Guriri, São Mateus,ES. Revista Brasileira de Biologia, vol. 57 , p. 647-654.

TEIXEIRA, RL., MILI, PSM. AND RÖDDER, D., 2006. Ecology of anurans inhabiting bromeliads in a saxicolous habitat of southeastern Brazil. Salamandra, vol. 42, p. 155163.

TEIXEIRA, RL. and RÖDDER, D., 2007. A rapid assessment of an anuran community inhabiting tank bromeliads in saxicolous habitat of southeastern Brazil. Amphibia, vol. 6 , p. 46-53. 
VAN SLUYS, M., ROCHA, CFD., HATANO, FH., BOQUIMPANI-FREITAS, L. e MARRA, RV., 2004. Anfíbios da restinga de Jurubatiba: composição de espécies e história natural. In ROCHA, CFD., SCARANO, FR. e ESTEVES, FA. (Eds.). Ecologia, história natural e conservação da restinga do Parque Nacional de Jurubatiba. São Carlos: Rima. p. 165-178.

VASCONCELOS, TS. e ROSSA-FERES, D., 2005. Diversidade, distribuição espacial e temporal de anfíbios anuros
(Amphibia: Anura) na região noroeste do Estado de São Paulo. Biota Neotropical, vol. 5, no. 2, p. 1-14.

VELOSO, HP., RANGEL FILHO, ALR. e LIMA, JCA., 1991. Classificação da vegetação brasileira adaptada a um sistema universal. Rio de Janeiro: IBGE. $124 \mathrm{p}$.

ZAR, JH., 1999. Biostatistical analysis. 4th ed. New Jersey: Prentice Hall. 663 p. 